\title{
A First Glimpse of the Late Neolithic and Early Chalcolithic in Cappadocia through the Lithic Industry of Tepecik-Çiftlik 2017 Season
}

Alice Vinet and Denis Guilbeau

\section{(2) OpenEdition Journals}

Electronic version

URL: https://journals.openedition.org/anatoliaantiqua/517

DOI: 10.4000/anatoliaantiqua.517

Publisher

IFEA

Printed version

Date of publication: 1 December 2018

Number of pages: 1-12

ISBN: 9782362450747

ISSN: $1018-1946$

Electronic reference

Alice Vinet and Denis Guilbeau, "A First Glimpse of the Late Neolithic and Early Chalcolithic in Cappadocia through the Lithic Industry of Tepecik-Çiftlik 2017 Season", Anatolia Antiqua [Online], XXVI ] 2018, Online since 17 July 2019, connection on 03 September 2021. URL: http://

journals.openedition.org/anatoliaantiqua/517 ; DOI: https://doi.org/10.4000/anatoliaantiqua.517 


\section{ANATOLIA ANTIQUA ESKI ANADOLU}

\section{XXVI}

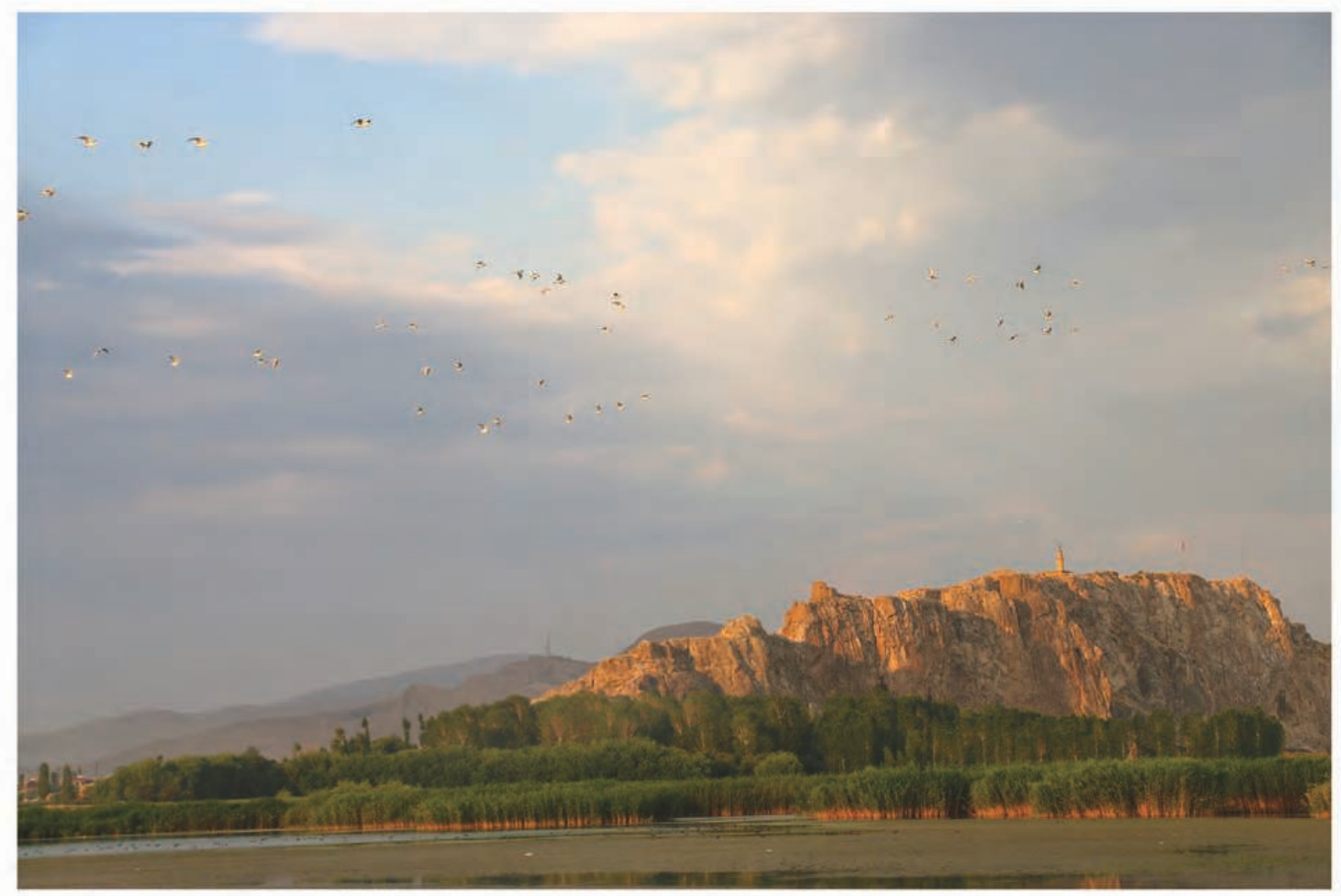

INSTITUT FRANÇAIS D'ETUDES ANATOLIENNES GEORGES-DUMEZIL

CNRS USR 3131

DE BOCCARD 


\section{TABLE DES MATIERES}

Alice VINET et Denis GUILBEAU

A First Glimpse of the Late Neolithic and Early Chalcolithic in Cappadocia through the Lithic

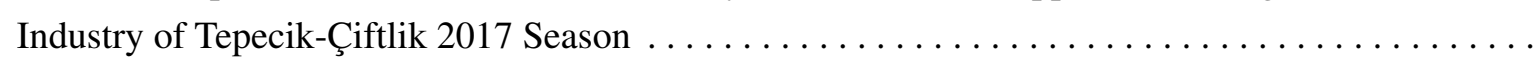

Ergül KODAŞ, Haluk SAĞLAMTIMUR et Yılmaz Selim ERDAL

Three Human Graves of the Hassuna Culture in Türbe Höyük

\section{Kevin PARACHAUD}

Les Galates en Asie Mineure au regard de la culture matérielle. Hellénisation, maintien, acculturation ? 23

H. Asena KIZILARSLANOĞLU et Erkan ALKAÇ

Hellenistic Amphora Stamps from Elaiussa . . . . . . . . . . . . . . . . . . . . .

Aygün EKİN MERİÇ

Late Roman Pottery from the Theatre of Nicaea in Bithynia $\ldots \ldots \ldots \ldots \ldots \ldots \ldots \ldots \ldots$

Nergis GÜNSENIN

La typologie des amphores Günsenin. Une mise au point nouvelle.

Nergis GÜNSENIN et Alessandra RICCI

Les amphores Günsenin IV à Küçükyalı (Istanbul). Un voyage entre monastères ? . . . . . . . . . .

\section{CHRONIQUES DES TRAVAUX ARCHEOLOGIQUES EN TURQUIE 2017}

Erkan KONYAR, Bülent GENÇ, H. Banu KONYAR, Armağan TAN et Can AVCI

Excavations at the Old City, Fortress, and Mound of Van: Work in 2017 . . . . . . . . . . . . . .

\section{Çiğdem MANER}

Preliminary Report on the Fifth Season of the Konya Ereğli, Karapınar, Halkapınar and

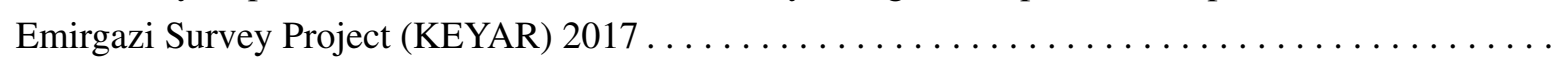

Abuzer KIZIL, Koray KONUK, Taylan DOĞAN, Didier LAROCHE, Enora LE QUERE,

Vasilica LUNGU, Francis PROST et Baptiste VERGNAUD

Eurômos : Rapport préliminaire sur les travaux réalisés en 2017

Olivier HENRY et E. ANDERSSON, J. BLID, Chr. BOST, Ö. ÇAKMAKLI, N. CARLESS-UNWIN, G. ÇİMEN, A. EYİGÖR, A. FRECCERO, A. FREJMAN, Cr. GEORGESCU, E. GOUSSARD, A.-M. GUIMIER-SORBETS, M. HAUCHART, R. HEDLUNG, N. LAMARE, V. LUNGU, Fr. MARCHAND-BEAULIEU, A. SITZ, I. STOJANOVIC, B. VERGNAUD 


\section{A FIRST GLIMPSE OF THE LATE NEOLITHIC AND EARLY CHALCOLITHIC IN CAPPADOCIA THROUGH THE LITHIC INDUSTRY OF TEPECIK-ÇIFTLIK 2017 SEASON}

We are quite well informed on the dynamics for the Neolithic periods in Central Anatolia, and a lot of studies were undertaken to document the economic and cultural changes that appear during this key period. But there is a real lack of technological and functional data analysis for the Chalcolithic. Though the subsistence economy is still based on agriculture it has evolved since the beginning of plant domestication. Technical skills change through time and we can document this evolution with techno-functional studies of obsidian tools assemblages.

Tepecik-Çiftlik was inhabited from the PPN to the Early Chalcolithic, from the beginning of the $7^{\text {th }}$ millennium to the beginning of the $6^{\text {th }}$ millennium. The settlement is located in a circumscribed plain in the southern part of Cappadocia, $1500 \mathrm{~m}$ above the sea level, very close to the obsidian outcrops of the Göllüdağ and the Nenezidağ (Fig. 1). Its location is ideal to question the management of the outcrops, the Cappadocian obsidians trade and the cultural and economic links that emerge from exchange networks. This paper is also tackling the traditions related to the exploitation of obsidian: the knapping techniques involved, the skills required for the production of a toolkit and its use.

The site has been excavated since 2000 by the Prehistory Department of the Istanbul University under the direction of Erhan Bıçakçı (Istanbul University) ${ }^{1}$. Since 2016, the program "Melendiz Préhistorique" directed by Martin Godon (French Institute for Anatolian Studies) is supporting our research. In 2017, the excavation focused on the western part of the mound, especially the squares 15J, 15I and 16I, where the Early Chalcolithic (level 2: from ca. 6000 cal BC) and the Late Neolithic levels (level 3, ca. 6300-6000 cal BC) are the best preserved $^{2}$.

The last field season has fulfilled the team's expectations: we understand better the transition between Late Neolithic and Early Chalcolithic and the architecture associated with these levels. Indeed, four phases of development have been noticed during the Early Chalcolithic. New $\mathrm{C}_{14}$ samples were taken inside silos and they will help the team precise the timeline of the level 2 occupation.

\section{CHIPPED STONE ANALYSIS}

\section{General data}

This paper focuses on the chipped stone industry uncovered during the 2017 field season. The excavated area represents about $250 \mathrm{~m}^{2}$ (Fig. 2). This part of the mound is interpreted as a dwelling area and is shaped by several domestic structures, some of which are related to the everyday life such as storage pits, silos, ovens or hearths. When the settlement was abandoned, some components of the toolkit (pottery, grinding stones, obsidian implements) and a lot of the waste produced in the making of these tools were left behind. Therefore, a lot of artefacts are found, some of them in situ, others in secondary positions.

All the chipped stones found during the 2017 season were registered $(n=6308)$, apart from the small chips produced by knapping activities and post-depositional alterations. The methodology used to undertake this project was designed to adequately fit the field's schedule. Indeed, only the main characteristics of the blanks were registered. Our purpose is to describe the main features of the chipped

*) Alice Vinet, Université Paris 1 Panthéon Sorbonne, UMR 8215 Trajectoires, UMR 7264 CEPAM, Nanterre and Nice, France. Denis Guilbeau, Ministère de la Culture, UMR 7055 Préhistoire et Technologie, Nanterre, France.

1) Tepecik-Çiftlik excavation is supported by: Istanbul University Research Project (BAP) number 25460 and the General Directorate of Antiquities and Museum.

2) Bıçakçı et al. 2017. 


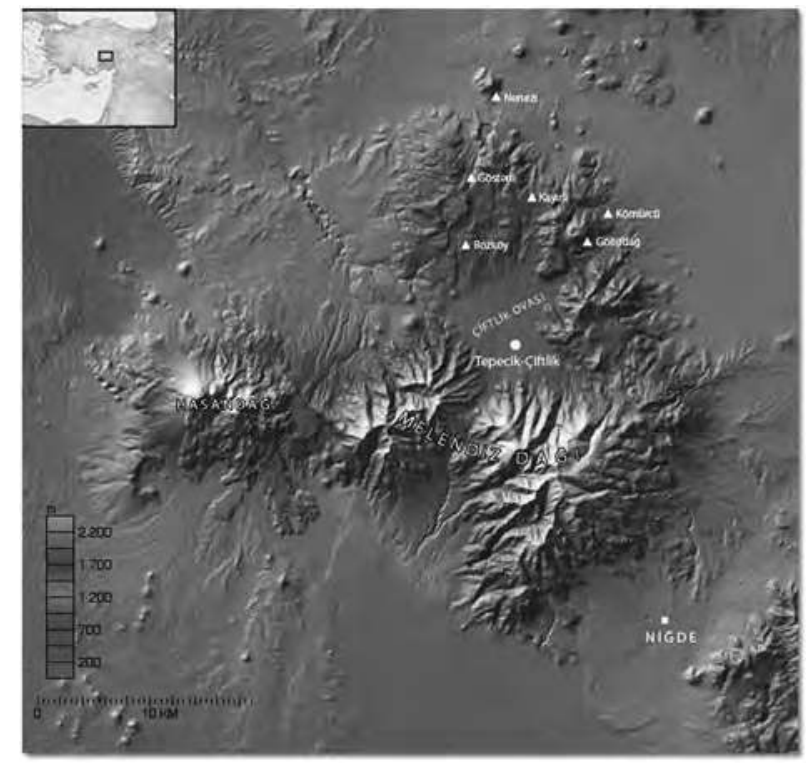

Fig. 1: Location of the site and the obsidian sources (M. Godon).

stone industry, as no precise data was ever recorded for these levels ${ }^{3}$. Furthermore, compared to the size of the site -3.5 ha- the area considered here is rather small. Hence, the analysis presented below do not precisely reconstruct the chaînes opératoires and the toolkit management for the site at this period. Nevertheless, the study gives new insights on the organization of this Neolithic-Chalcolithic community and its relationship with this predominant raw material -the obsidian of Cappadocia.

The strong alterations and the high fragmentation of the implements did not prevent the study of the chaînes opératoires and the toolkit management. The overall analysis shows that there is no sharp evolution in the chipped stone management between the Late Neolithic and the Early Chalcolithic. Therefore we will comment the chipped stones from the two levels together.

\section{Raw materials}

Almost the entire lithic industry is made of obsidian. Indeed only $0.3 \%$ of the chipped stones (17 implements) recorded in 2017 is made of non-obsidian raw materials.

Nine out of seventeen implements were knapped on a likely siliceous stone, yet impossible

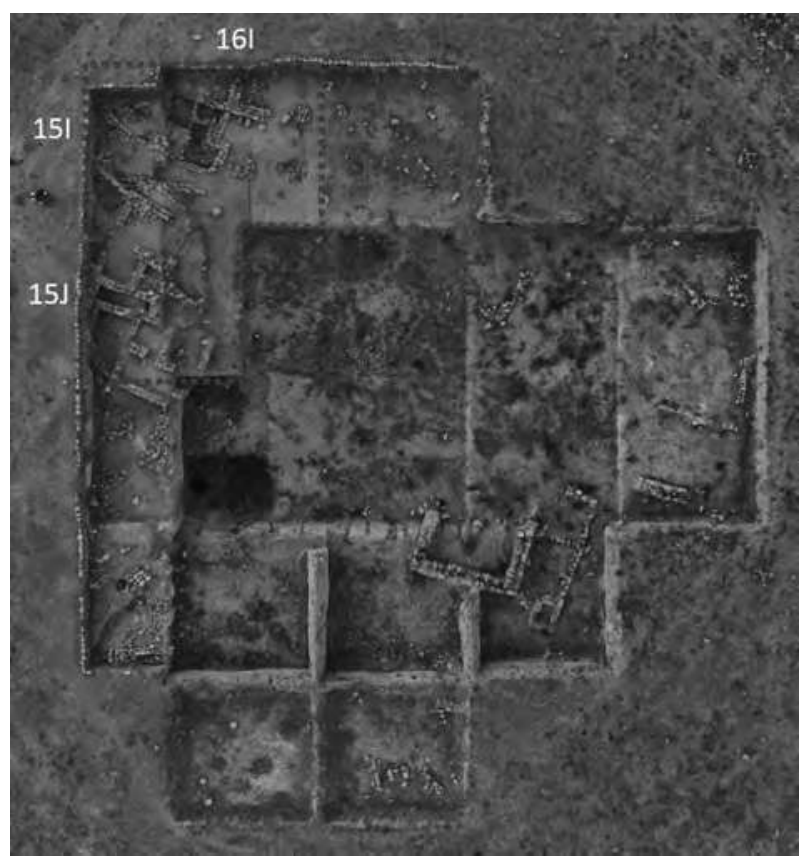

Fig. 2: Excavated areas during the 2017 field season (excavation team).

to precisely characterise because the stones are totally burnt. Four other artefacts were made of flint. Various macroscopic features are observable, these should correspond to different raw materials. One flake is made of a light brown-reddish flint, opaque and banded, with a low percentage of whitish cortex on the distal part. One blade is made of a beige, very fine grained, patinated flint with whitish zones, another is made of a translucent pinkish-beige flint, with large spots. Finally, three artefacts are made of a volcanic rock and one was knapped on quartz.

The broad identification of the non-obsidian raw materials is usually reachable. However, it's a lot more complicated for the obsidian. Provenance studies are yet to come at Tepecik, anyway the obsidian used at the site is rather likely to come from the nearest outcrops. The Göllüdağ volcano is less than $10 \mathrm{~km}$ away from the site, and the Nenezidag volcano is about $23 \mathrm{~km}$ distant from the settlement.

N. Kayacan developed a methodology to source obsidian based on visual characterization, using the Çatalhöyük East Mound as a case study ${ }^{4}$. She used several macroscopic criteria, such as colour, inclusions or translucency to define obsidian types. Later on, M. Milić and her colleagues continue this work by verifying the visual determinations with elements characterisation and blind tests ${ }^{5}$. The ob-

3) Some elements were published in 2012 by E. Bıçakçı, M. Godon And Y.G. Çakan.

4) Özbasaran and Duru 2014.

5) Milić et al. 2013. 
sidian of Göllüdağ has a relatively limited macroscopic variability compared to other deposits, so it is possible to identify quite easily the pieces which differ from the rest of the industry. The broad majority of the Tepecik obsidians might be at first linked to the Göllüdağ. However, many implements exhibit macroscopic features which could be related to the Nenezidağ obsidians. Moreover, we cannot exclude that some obsidian artefacts might come from more distant outcrops, such as Acıgöl or even from further deposits. Indeed, few implements are made of a different obsidian, completely opaque with a grey-greenish colour. Its macroscopic features do not match the criteria used to describe the Göllüdağ nor the Nenezidağ obsidian.

The time is now to make a proper analysis to source the different raw materials found at Tepecik. It will be particularly interesting to confirm or deny the eventual exogenous origin of some obsidian tools.

\section{Organization of the chaînes opératoires in obsidian}

About half of the chipped stone industry $(\mathrm{n}=$ 3041/6291) can be defined as "debris" (Table 1). The term is used here to describe heavily fragmented blanks which cannot be assigned to any specific step in a chaîne opératoire. The upper and lower faces of these shapeless fragments are no longer distinguishable.

Blades and fragments of blades are quite numerous $(n=562)$. Furthermore, some debris must correspond to fragment of blades and a lot of points were probably made on blade but their blank is too retouched to be recognizable.

Only a fraction of the numerous flakes was related to the blade production. The rest of the flakes can be linked to one or several chaîne(s) opératoire(s) dedicated to the production of flakes. Hence, there are at least two productions, one to produce blades and another for flakes. The technological study shows that the two productions are quite diversified.

\section{Flake production}

1436 flakes which could not be clearly associated to a blade production were registered. Their dimensions and their morphology vary a lot. The majority is about 6 to $7 \mathrm{~cm}$ in length. The presence of 149 flake cores indicates that at least some flakes were knapped on site by hard direct percussion.

Some flakes were produced using the anvil and hammer technique. The cores and flakes are similar to splintered pieces. It is not yet possible to determine if this technique was specifically used to produce flakes or if they appear to be an accidental result of the use of splintered pieces as tools. This production is not evenly distributed among the site as it was only observed in some units so far.

There is a third production of large and thin flakes, the biggest one measures more than $13 \mathrm{~cm}$ long and no more than $0.95 \mathrm{~mm}$ thick. The prehistoric knappers had enough skills to master the production of very large, regular and thin flakes in obsidian. No evidence shows that they were knapped on site, however it is possible that the cores were re-used in other chaînes opératoires and might be no longer recognizable.

Table 1: Technical categories of the obsidian chipped stones (D. Guilbeau).

\begin{tabular}{|l|r|}
\hline Flakes & 1436 \\
\hline Flake cores & 149 \\
\hline Central blades & 377 \\
\hline Upsilon & 53 \\
\hline Crested or cortical blades & 18 \\
\hline Undercrested blades & 0 \\
\hline Lateral blades & 99 \\
\hline Technical blades & 15 \\
\hline Flakes from blade cores & 85 \\
\hline Blade cores & 1 \\
\hline Rejuvenation flakes & 5 \\
\hline Shaping flakes & 310 \\
\hline Cortical flakes & 655 \\
\hline Blocks & 3 \\
\hline Undetermined & 44 \\
\hline Debris & 3041 \\
\hline Total & $\mathbf{6 2 9 1}$ \\
\hline
\end{tabular}

\section{Blade production}

About 963 chipped stones are blades or chipped stones related to the blade production (Table 2). They correspond to several chaînes opératoires made with different techniques and methods and related to blanks of diverse morphologies.

Despite the fact that these elements come from various chaînes opératoires, general aspects can be underlined. 
Table 2: Technical categories of obsidian chipped stones related to the blade production.

\begin{tabular}{|l|r|}
\hline Blades & 377 \\
\hline Lateral blades & 99 \\
\hline Technical blades & 15 \\
\hline Upsilon & 53 \\
\hline Crested or cortical blades & 18 \\
\hline Undercrested blades & 0 \\
\hline Rejuvenation flakes & 5 \\
\hline Shaping flakes & 310 \\
\hline Flakes from blade cores & 85 \\
\hline Blade cores & 1 \\
\hline Total & $\mathbf{9 6 3}$ \\
\hline
\end{tabular}

First of all, no blade core was uncovered apart from a small one made on a pebble. The lack of blade cores does not necessarily mean that blades were not produced on site. Surely, we cannot exclude the reuse of some cores in other chaînes opératoires for the production of flakes. Indeed, among the flakes registered: 85 originate from blades cores and 310 were associated, based on their morphology, to the preparation of blade cores. Furthermore, some blades were produced in the processing steps of the blade production such as the 18 crested or cortical blades made during the shaping of the core or the 99 lateral blades and the 15 technical blades which maintain the core's shape during the plein débitage phase. Even if most of the lateral blades are unipolar, it is yet impossible to determine which blade chaîne opératoire took place on site. As we briefly stated above, the industry is not homogeneous among the different buildings and units. The area excavated in 2017 is not large enough to have a perfect understanding of the knapping activities on site. The upcoming field seasons will certainly give us the opportunity to get more data and complete this study.

Most of the blades are irregular and could be described as laminar flakes. Most of this low-skilled production was performed by hard direct percussion, but some were knapped by direct percussion with a soft stone. The other blade productions are far more difficult to characterize because of the scarcity of diagnostic chipped stones among this industry.
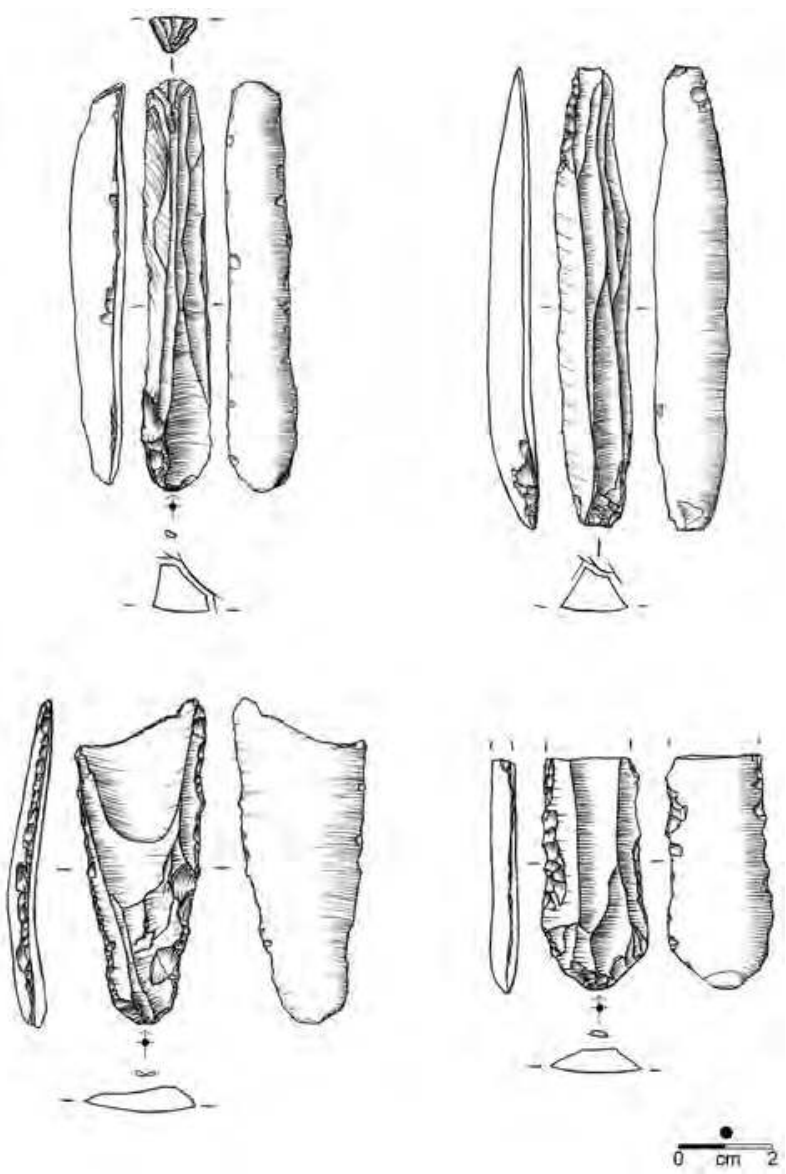

Plate 1: Some blades (drawings by D. Guilbeau).

The only production clearly identifiable is performed on bipolar cores, and corresponds to a predetermined-upsilon knapping ${ }^{6}$. There are 53 upsilon blades or blade fragments. Their morphology varies a lot (width, thickness) but most of them measures about $50-60 \mathrm{~mm}$ in length. According to the negatives of removals, the upsilon blades can be associated to the production of regular thick blades, of triangular or subtriangular section. Blanks clearly linked to this production are hard to identify because of the fragmentation of the blade production and the extensive retouch on lot of them. Only four almost complete blades are documented. We identified 31 central blades flaked from bipolar cores, but a larger number must have been flaked. Indeed, many of them must have been used for the production of points and we can no longer recognize their blanks. Upsilons and blades were knapped by very skilled knappers. The technique used to produce at least one part of the blades is the direct percussion with a soft stone.

Finally, it should be noted that eight unipolar blades may have been pressure-flaked. Indeed, a few 
essential recognition criteria can be observed on these blades. They are very regular and thin with parallel edges and arises, and a constant thickness without waves. Three of them have a thin plain platform without any crack and with a preserved lip, and a ripple is clearly visible under the bulb of one of them. Their width varies from 7.5 to $22 \mathrm{~mm}$ so they could have been flaked by several "modes" of pressure ${ }^{7}$ (one to four). However, the distinction between this technique and the soft direct percussion technique is complicated. Therefore, we need more data to confirm the marginal presence of pressure-flaked blades at Tepecik-Çiftlik during the Early Chalcolithic.

\section{Productions made on other raw materials}

As previously mentioned above, the non-obsidian raw materials are rare. The assemblage is small, therefore we will only briefly comment these productions.

Two fragmented blades, likely made of the same raw material, might be pressure-flaked. The width of one of them reached $26.5 \mathrm{~mm}$ before it was retouched. This blade would be associated with the mode $5^{8}$ of the pressure technique, using a lever. However, we cannot exclude yet a very fine indirect percussion knapping.

Other raw materials (quartz, a potential siliceous rock, volcanic rocks) appear only in the form of flakes and debris $(\mathrm{n}=13)$. There are also two flakes made of flint, including one rather large (about $5.5 \mathrm{~cm}$ ).

\section{Toolkit}

The word toolkit encompasses here every retouched object, whether it's complete or fragmented (Table 3). The definition does not include the unretouched but used blanks. Some unretouched elements were part of the toolkit, as they have definitely been used. The use-wear conducted on some elements confirms it, but their frequency remains undetermined.

About 69 retouched blades and 57 flakes were registered among the 2017 lithic industry, they represent $55 \%$ of the toolkit. Most of the retouched blades are fragmented, whereas there are numerous complete flakes. Their average dimensions are 55 $\mathrm{mm}$ in length, $40 \mathrm{~mm}$ in width and $9 \mathrm{~mm}$ thick. For both categories the location, the extension and the delineation of the retouch vary a lot.

\begin{tabular}{|l|r|r|c|r|}
\hline & Flakes & Blades & Undetermined & Total \\
\hline Retouched blades & 0 & 69 & 0 & 69 \\
\hline Retouched flakes & 55 & 0 & 2 & 57 \\
\hline Points & 1 & 17 & 37 & 55 \\
\hline Scrapers & 12 & 7 & 10 & 29 \\
\hline Burins & 0 & 8 & 0 & 8 \\
\hline Notches & 0 & 3 & 0 & 3 \\
\hline Borers & 0 & 2 & 1 & 3 \\
\hline Beaks & 1 & 1 & 0 & 2 \\
\hline Truncation & 0 & 1 & 0 & 1 \\
\hline TOTAL & $\mathbf{6 9}$ & $\mathbf{1 0 8}$ & $\mathbf{5 0}$ & $\mathbf{2 2 7}$ \\
\hline
\end{tabular}

Table 3: Toolkit.

Points and foliates $(n=55)$ represent a large part of the toolkit since the earliest levels ${ }^{9}$. Various types exist among the corpus, some have a long and narrow tang, and others have a leaf shape without a tang. Some points are perfectly symmetrical on the longitudinal axe, other are quite irregular. Bipolar blades were used as blanks at least for some of the points, especially the ones from the predetermined upsilon production. Every point was retouched using the pressure technique. The extension of the retouch varies, it can be limited to the edges or cover one or both faces. The dimensions are also quite diversified, the longest ones are about $10 \mathrm{~cm}$ long (Graph 1). The points of several excavation seasons are currently being investigated in order to better characterize their manufacture and their typology. We already noticed evidences of use as projectiles on some of them (impact fracture).

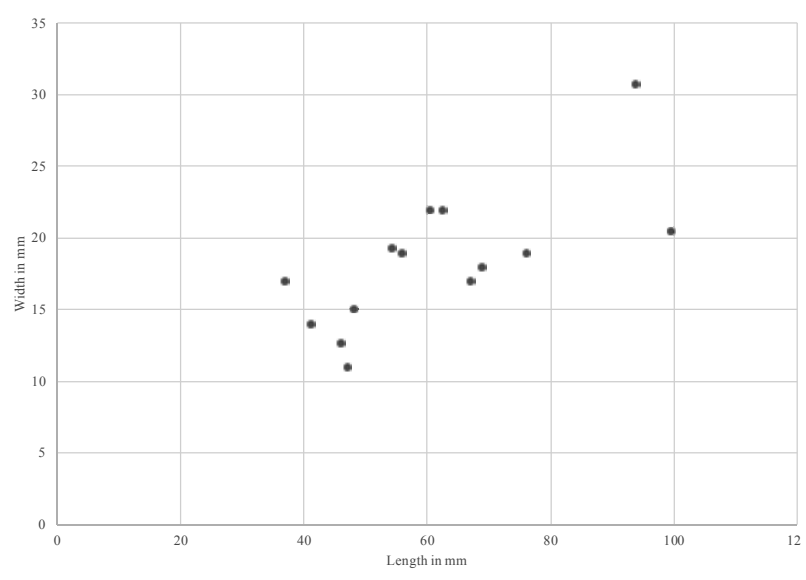

Graph 1: Dimensions of the complete points.

7) Pelegrin 2012

8) Pelegrin 2012.

9) Bıçakçı et al. 2012 
Scrapers are quite numerous among the toolkit $(\mathrm{n}=29)$. It is the most diverse typological category of tools, some are made on flakes others on blades. The short direct retouch focuses on the distal ends of the blanks shaping convex edges with an abrupt angle.

The rest of the toolkit include burins $(\mathrm{n}=8)$, notches $(n=3)$, borers $(n=3)$, beaks $(n=2)$ and truncations $(\mathrm{n}=1)$. Almost all of them are made on blades.

\section{USE-WEAR ANALYSIS}

\section{Methods}

This paper also aims to report the first functional analysis made on a selection of the 2017 chipped stones. We combined both the Low Power Approach $^{10}$ and the High Power Approach ${ }^{11}$ to describe and interpret the macroscopic and the microscopic wears. In this research the macro-scales observations were carried out at Tepecik with a stereo-microscope Leica EZ4 W with magnifications from $8 \mathrm{x}$ to $35 \mathrm{x}$. They were completed by micro-scaled observations at the Prehistory Department of the Istanbul University using the Nikon LV150 metallographic microscope.

On site, a first sorting of the material was made based on observations with the naked eye, all the debris, the highly fragmented and/or damaged pieces were disregarded. The material left represents less than $10 \%$ of the assemblage. This first selection was then examined under low magnifications with a stereoscopic microscope to sample the tools showing well developed and preserved use-wears. Besides the points, 42 implements were selected for an exhaustive use-wear analysis. All but two are made of obsidian.

\section{Post-depositional surface modifications}

The obsidian artefacts are exposed to post-depositional surface modifications (PDSM), in the ground and also after being unearthed. The PDSM can take various forms such as patina, matte gloss, abrasion spots, striations or edge damage.

At Tepecik, a large part of the tools has been excluded from the selection due to a poor conservation of the use-wears. Indeed, post-depositional modifications affect the surface of a great number of tools, until sometimes covering any traces of use. We notice very frequently thick patinas that abrade and give a matte and uneven aspect to the obsidian artefacts. Their intensity and development may vary, but, in many cases, it prevents any hypothesis regarding the function(s) of the implements. Thinner patinas develop on the assemblage in the form of matte gloss which spread on large part or the entire implements. Its affects the analysis depending on their distribution and intensity. Chipped stones exhibit often abrasion spots distributed randomly on their faces and edges. They are almost never linked with use and usually don't prevent functional interpretation. Similarly, secant striations are observable on both ventral and dorsal faces of the implements, and are easily distinguishable from striations caused by use. The lack of storage space altered the assemblage. Indeed, numerous chipped stones are stored together in one bag. The constant contact between them causes edge-damage. Sometimes, the micro-flaking is quite extensive and has removed the traces of use and may be perceived as actual use-wears. Finally, we witness a few cases of a dissolution of the surface caused by a yet unknown physiochemical phenomenon which prevents any use-wear analysis.

This differential preservation of the use-wears has several consequences on the overall functional interpretation of the assemblage. Mainly the activities employing hard materials or very intense work of soft materials are observable. Thus, we already take note of an overrepresentation of the activities related to the work of abrasive materials such as hide and soft stones. Similarly, the plant materials are under-represented among the sample and the activities, which leave minimal traces on the implements, like butchery are totally absent. Therefore, the use-wear study conducted at Tepecik is not representative of the activities that occurred on site and nearby, but gives information about the presence of some activities and the way they were performed.

\section{General data}

The results presented below correspond to half of the 2017 material selected for a complete usewear analysis. We only selected tools from secure contexts which display preserved use-wears and for which an interpretation could be suggested. The selection is composed of 21 tools of which 11 were used on several active parts leading to 35 used zones (Table 4). Below, we describe the recorded data and suggest preliminary interpretations which might evolve in the future. These few preliminary

10) Tringham et al. 1974.

11) Keeley 1980. 
Table 4: Used zones.

\begin{tabular}{|c|c|c|c|c|c|}
\hline $\mathbf{N}^{\circ}$ & \multicolumn{2}{|c|}{ Blank } & Used Zone & Motion & Worked material \\
\hline 435 & Blade & Distal & Right edge & Cutting & Cereals \\
\hline \multirow{2}{*}{436} & \multirow{2}{*}{ Blade } & \multirow{2}{*}{ Mesial } & Left edge & Longitudinal & Hard material \\
\hline & & & Right edge & Cutting & Rigid-tender plants \\
\hline \multirow{2}{*}{437} & \multirow{2}{*}{ Blade } & \multirow{2}{*}{ Mesial } & Left edge & Cutting \& scraping & Hide w/ additive or clay \\
\hline & & & Right edge & Cutting \& scraping & Hide w/ additive or clay \\
\hline \multirow{2}{*}{438} & \multirow{2}{*}{ Flake } & \multirow{2}{*}{ Mesial } & Left edge & Scraping & Hide w/ additive or clay \\
\hline & & & Right edge & Scraping & Hide w/ additive or clay \\
\hline 439 & Blade & Proximal & Right edge & Cutting & Cereals \\
\hline 440 & Blade & Mesial & Left edge & Cutting & Plants \\
\hline 441 & Blade & Distal & Distal end & Drilling & Hard material (mineral?) \\
\hline \multirow{2}{*}{442} & \multirow{2}{*}{ Blade } & \multirow{2}{*}{ Mesial } & Left edge & Sawing & Hard material \\
\hline & & & Distal end & Carving & Hard material \\
\hline 443 & Blade & Proximal & Proximal end & Carving & Hard material (mineral?) \\
\hline \multirow{2}{*}{444} & \multirow{2}{*}{ Blade } & \multirow{2}{*}{ Distal } & Left edge & Scraping & Hard material \\
\hline & & & Right edge & Sawing & Hard material \\
\hline \multirow{2}{*}{445} & \multirow{2}{*}{ Blade } & \multirow{2}{*}{ Mesial } & Left edge & Smoothing/polishing & Mineral \\
\hline & & & Right edge & Scraping & Mineral \\
\hline \multirow{2}{*}{446} & \multirow{2}{*}{ Blade } & \multirow{2}{*}{ Proximal } & Left edge & Sawing & Wood \\
\hline & & & Right edge & Sawing & Wood \\
\hline 447 & Blade & Distal & Right edge & Sawing & Hard material \\
\hline \multirow{2}{*}{448} & \multirow{2}{*}{ Blade } & \multirow{2}{*}{ Complete } & Left edge & Cutting & Rigid-tender plants \\
\hline & & & Right edge & Cutting & Herbaceous plants \\
\hline \multirow{3}{*}{449} & \multirow{3}{*}{ Blade } & \multirow{3}{*}{ Complete } & Left edge & Scraping & Hide \\
\hline & & & Left edge & Cutting & Bone? \\
\hline & & & Right edge & Scraping & Hide \\
\hline & & & Left edge & Sawing & Rigid-tender plants \\
\hline 450 & Blade & Proximal & Right edge & Sawing & Rigid-tender plants \\
\hline 451 & Flake & Distal & Distal end & Carving? & Soft material \\
\hline 452 & Blade & Distal & Right edge & Sawing & Wood \\
\hline & & & Distal end & Grooving & Mineral \\
\hline 453 & Flake & Proximal & Distal end & Grooving & Mineral \\
\hline 453 & гаке & Proximal & Distal end & Scraping & Mineral \\
\hline & & & Proximal end & Grooving & Mineral \\
\hline 454 & Blade & Complete & Right edge & Sawing & Wood \\
\hline 455 & Blade & Complete & Right edge & Cutting & Hide \\
\hline & & & TOTAL & SED ZONES : 35 & \\
\hline
\end{tabular}


elements give us some information about the toolkit management despite an overrepresentation of the hard materials. We can see a rich diversity of craft activities encompassing basketry, archery, plaiting, bead and figurine manufacturing, pottery making among others. The rich material culture uncovered on site over the years match the use-wear analysis. Indeed, many beads, pottery and figurines were found and now we have some evidences that they could all have been produced on site.

Activities related to the daily subsistence such as cereal harvesting or wood working also occur among the sample. These activities are typical of the sedentary lifestyle Neolithic communities were pursuing with agriculture and animal husbandry.

\section{Cereal harvesting}

Two blades (two used zones) exhibit diagnostic use-wears associated with cereals processing. They were both interpreted as sickles blades.

The first sickle blade made of a good quality fine grain yellow-beige flint was maybe manufactured with the lever pressure. The active edge displays a direct short abrupt retouch creating an open angle. A regular edge-rounding is observable as well as large and bright polished areas forming a gloss (Fig. 3). The polished areas developed as a dense band parallel to the edge gradually decreasing. The micro-topography is smooth and slightly domed. It is associated with a few dotted striations on the ventral face, parallel to the edge indicated a cutting motion.

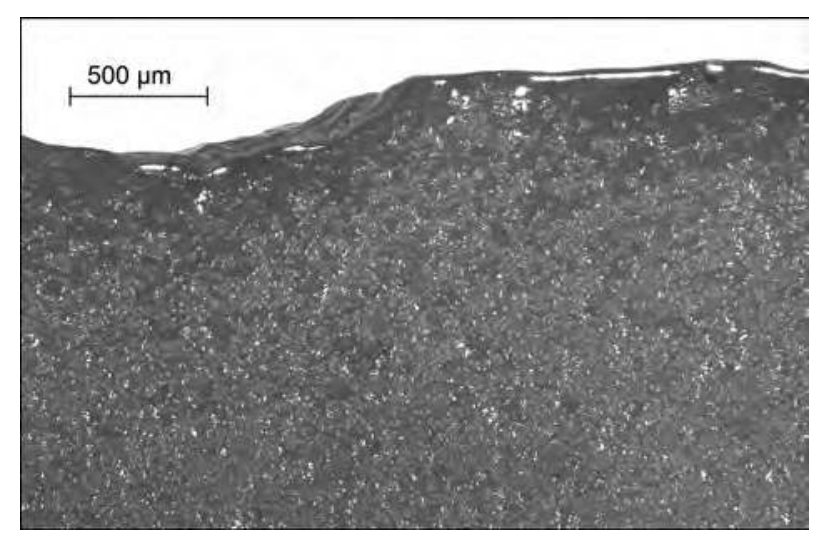

Fig. 3: Edge-rounding and polish areas on a sickle insert (A. Vinet).

The second sickle insert is a transparent obsidian blade with a truncation. The unretouched right edge shows a clear matte gloss, more extended on the ventral face. The use-wears have been altered by post-depositional micro-flaking which makes the interpretation hard to process. Numerous long and thin striations are observable on both faces parallel to the edge indicating again a cutting motion.

On both tools, the polished areas are not very extended suggesting a deep parallel insertion into the haft. Few hafts made of bone were uncovered at Tepecik. It would be very interesting to compare the hafts to the sickles to see if they match.

It may be noted that the Tepecik inhabitants chose to use flint as sickle elements despite their obvious scarcity.

\section{Plants processing}

Four tools corresponding to six distinct used zones have processed a range of wild plant species: rigid-tender plants such as reed or wicker and herbaceous plants with softer stems.

The implements are all retouched but one and made of obsidian. Their active edges display a long direct semi-abrupt to abrupt retouch, subparallel or scaled. No gloss or edge rounding were observed on these blades which might be due to alterations. The outlines of the used zones are well defined, in one case by a post-use fracture, otherwise by a very regular micro-flaking. Their number and size vary according the characteristics of the edge. They always display a feather termination. Polished areas are very rare due to the edge removals caused by use or post-depositional alterations. They are marginal and can only be observed on the protruding areas of the topography which appear domed or domed stretched, with a smooth texture. The six used zones share the same striations with few variations. They develop parallel or slightly inclined to the edge, suggesting cutting or sawing motions. They appear in a high amount on both faces as dense dotted long and thin striations and are associated with the work of rigid-tender plants with semi-hard stems. One used zone shows more delicate traces which we interpreted as herbaceous processing. Finally, one tool shows altered traces for which it is not possible to offer a detailed interpretation.

These implements could have been used in numerous activities such as basketry, archery, plaiting, textile manufacturing. More evidences of these crafts activities were found at Tepecik. Baskets impressions were found on numerous pottery vases linked with casting in concave or convex moulds ${ }^{12}$. 


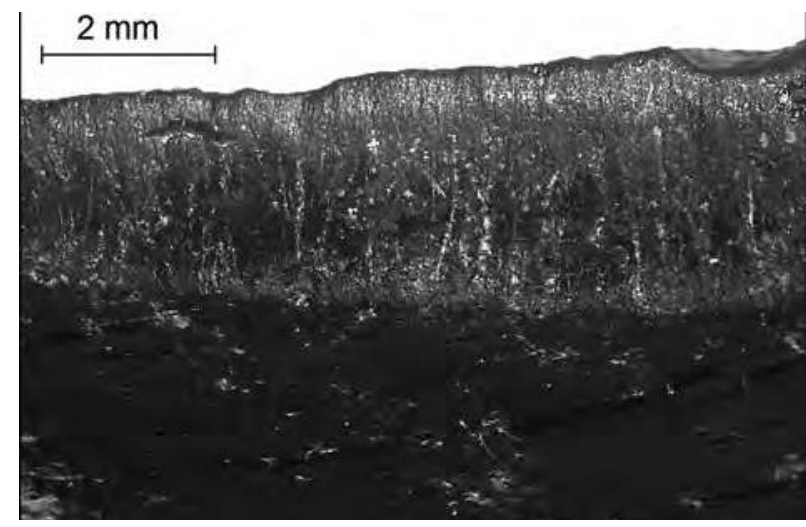

Fig. 4: Edge-rounding, abrasion and striations exhibited on the left edge of a blade (A. Vinet).

\section{Wood working}

Wood working is represented by three tools corresponding to three used zones which display well preserved use-wears. Besides their use-wears they share strong and thick sharp edges, suggesting that the production of thicker blades is oriented towards processing harder materials.

A retouched upsilon blade $(77 \times 41 \times 7 \mathrm{~mm})$ made of obsidian processed wood with its left edge. It exhibits a direct semi-abrupt long and scaled retouch shaping a thick edge. It must have been abandoned after its resharpening because only a small area (5 mm long) on the ventral face displays use-wear. Therefore, the edge shows very little micro-flaking with small, close, hinge-step, bifacial removals. A little symmetrical abrasion of the edge is observable on the preserved area. It is associated with numerous large and long abraded striations displayed mostly on the ventral face parallel to the edge. These traces suggest a back and forth motion like sawing.

The second blade processed wood on both edges. It is an almost complete blade of $120 \mathrm{~mm}$ long which originally was about $140 \mathrm{~mm}$ long, made of a transparent obsidian. It displays a direct, low angle, scaled to subparallel and invasive retouch shaping thick convex edges. Both sharp edges show well preserved and developed traces of use. The absence of micro-flaking caused by use and the discontinuity of the polished areas and striations suggest that the edges were sharpened whilst sawing wood. Restricted polished areas with a domed topography appear on the edges. They are linked with a high number of long, large and abraded striations parallel to the edges. The traces suggest a fresh and/or humid wood.

Finally, a complete obsidian large flake (100 $\mathrm{x} 42 \times 15 \mathrm{~mm}$ ) was used on its right edge to cut wood. It is retouched on both edges with invasive,

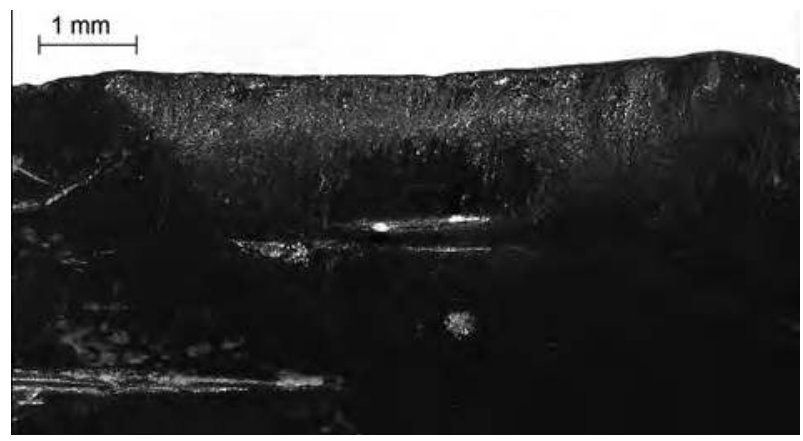

Fig. 5: Same blade, right edge (A. Vinet).

pressure-flaked removals on the left edge and short and abrupt removals on the right edge. Edge-damage is visible on the used edge, their big size, and step termination suggest the work of a hard material. Abraded areas are quite extended on the ventral face, levelling the protruding areas of the topography. They are associated with numerous short abraded striations parallel to the edge.

Many activities could match the traces, such as manufacturing hafts or bows, making planks etc.

\section{Mineral working}

Mineral working is represented by two tools among the 2017 selection. Indeed, they show a remarkable management of the active parts, using different angles on purpose for different tasks.

A first blade displays a short, sub-parallel direct retouch on the right edge probably for sharpening purposes. The left active edge displays a used zone very well defined by an intense uninterrupted edge-rounding (Fig. 4). The upper face shows a strong abrasion from the edge to the arris, suggesting that this part of the tool was used in a back and forth movement on a very abrasive but soft material. Numerous long and large striations are visible with higher magnifications. Alterations on both faces prevent any detailed interpretation of the abraded areas. Anyhow these traces can be linked to the polishing of a soft mineral. It could occur at the end of a "chaîne opératoire" for finishing operations for the production of figurines for instance or for burnishing pottery. The right edge displays the exact same use-wear (Fig. 5) the only differences are caused by the shape of the active edge. It generates a more developed edge rounding and less striations observable with a low magnification. With higher magnifications the traces are exactly similar, suggesting the same worked material with a different motion like scraping. 
Similar traces also interpreted as mineral processing have been notice on a flake which displays four distinct used zones. The flake was first retouched with long and scaled removals to create a thicker edge. It was then intentionally fractured on the distal part in order to create interesting angles to work with. The upper arris of the distal fracture shows traces that can be linked to the scraping of a hard mineral. We observe long and deep perpendicular abraded striations, large abraded zones and a completely flattened topography. The distal and end of both edges and the proximal end of the right edge exhibit the exact same traces with invasive edge-rounding, lots of abraded striations and no polish. The wears suggest a back and forth motion on a very abrasive material like a soft stone. It could be linked to figurines making, as many have been uncovered throughout the years, like creating thin and well-defined grooves to figure eyes, nose or mouth.

\section{Hide working}

Two complete and unretouched blades (about $60 \times 20 \times 7 \mathrm{~mm}$ ) display traces related to hide working.

The three used zones show regular micro-flaking with trapezoidal removals which size vary. One can observe a small band of bright polish parallel to the edge on the ventral face of the active edge associated with a cutting motion. The other two active edges scraped hide and the polish seem more irregular with a domed topography and a smooth texture. They exhibit a marginal discontinuous abrasion of the protruding areas. The three zones share the same short striations visible on the ventral face rather large, their quantity may vary according to the edge morphology and its topography.

It should be noted that one edge exhibits two used zones with overlapping traces of use, one transversal motion interpreted as scraping hide (described above) and one longitudinal motion linked with bone cutting.

These actions could correspond to several steps of the hide processing "chaîne opératoire" such as removing the hair and/or the fat from the hide.

\section{Hide working with additives or clay processing?}

Two tools corresponding to four distinct used zones display use-wear we cannot fully interpret yet.

It concerns one mesial fragment of a retouched blade with direct, semi-abrupt, long removals and one unretouched flake. The four used zones exhibit the same use-wears. First of all, a heavy edge rounding associated with a very extensive abrasion and large perpendicular striations are visible to the naked eye (see Fig. 6). With a higher magnification one can observe a lot of short and thin striations perpendicular to the edge or slightly inclined. Extensive polished areas tight together with a rough texture and rare craters are observable on the abraded areas. A different kind of polish is displayed on the ventral face with a smooth texture and a domedstretched topography.

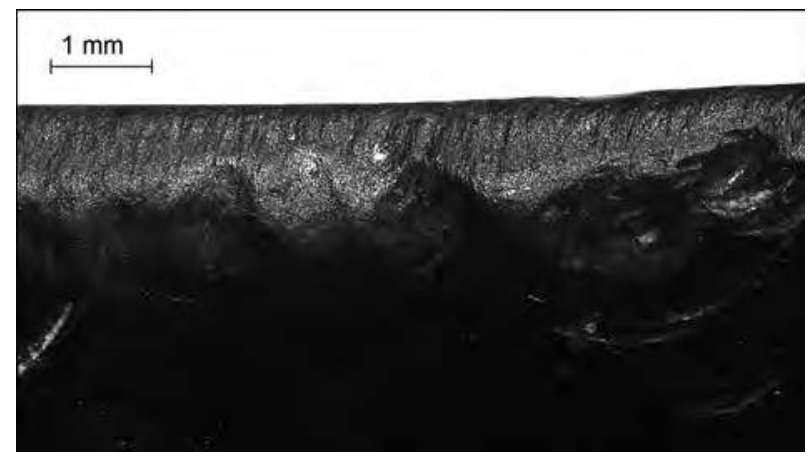

Fig. 6: Heavy edge-rounding, extensive abrasion and large striations (A. Vinet).

These use-wears could match motions which implies regular gestures such as stretching hide, the dorsal face would be in contact with the worked material. It could also match finishing stages in the pottery production like polishing or burnishing the clay when it is leather-hard. The technological analysis of the pottery assemblage made by Martin Godon revealed that both polishing and burnishing occured as finishing stages to even the surfaces. From the traces on the ceramics it is difficult to precisely determine the state of the clay when it was worked. Nevertheless, it appears that the scraping of the surfaces could have been carried out on a wet paste or on a leather-hard paste based on the location of the minerals inclusions.

\section{Hard and soft materials working}

After a macro- and microscopic analysis, nine used zones remain uninterpretable because of post-depositional alterations especially various forms of patinas and edge-damage. Most of these active edges were used to work hard material for various motions (drilling, sawing, carving, scraping). 


\section{DISCUSSION}

\section{Global consideration about the industry during the Late Neolithic and the Chalcolithic period}

D. Binder and his colleagues mentioned the decline of the naviform blade production at the end of the PPNB (last centuries of the $8^{\text {th }}$ millennium) and the end of the diffusion of the productions from Kaletepe $^{13}$. However, bipolar blade productions persist in different regions, especially in the south Levant ${ }^{14}$ but above all in Central Anatolia and in the Amuq region ${ }^{15}$. Even at the end of the $7^{\text {th }}$ millennium, such blade productions were still attested in these areas. The hypothesis of a recycling of upsilons and blades coming from ancient workshops can be ruled out ${ }^{16}$, because the frequency of such blades and their use as blanks for the main tool type of the site can be explained only by a production during this period. Those thick blades with a triangular or subtriangular section, naturally pointed, are the preferential blanks for such tools.

The knapping activities performed on site are little known. However, the abundance of points with very regular pressure retouch in different states of their manufacture and use indicates the likely presence of very skilled knappers. In the same time, a lot of products in the Late Neolithic and Chalcolithic levels of Tepecik-Çiftlik show a very low technical level, like the use of the hammer and anvil technique. We should not conclude that these knappings were performed by low skilled knappers. Indeed, a good knapper can use such a technique, obsidian was very easily available for the inhabitants of the site. Furthermore, the most skilled knappers could have been to the outcrops and make very good productions, such as large regular flakes or skilled bipolar blades and bring them back to their village. This may explain why this industry is characterized by the presence of a limited quantity of very good products mixed with a very large amount of debris and low skilled productions, like flakes.

\section{The place of Tepecik-Çiftlik in Central Anatolia during the Late Neolithic and the Chalcolithic}

Tepecik-Çiftlik is the closest village from the obsidian outcrops. The characteristics of the material culture, especially the pottery style, are similar to those of other sites throughout Central Anatolia, for instance Köşk Höyük, Gelveri, Pınarbaşı Bor, Mersin-Yümüktepe and, of course, Çatalhöyük.

The settlement is, first of all, a village occupied by farmers who were able to practice agriculture and animal husbandry in this fertile plain located on a high plateau.

The importance of obsidian in Neolithic-Chalcolithic communities and the frequency of such raw material in the site indicate that it was probably one of the reason why this community settled in this area. Furthermore, Tepecik-Çiftlik may have had a role in its distribution.

\section{CONCLUSION}

This study raises many questions, for instance the characterization of the chaînes opératoires needs to be precised in order to know which activities were performed on site and how. This will allow us to understand the possible role of the site in the distribution networks of obsidian, but also to understand how a Neolithic-Chalcolithic community was able to settle successfully in a very special and harsh environment.

A.V. et D.G.

\section{Acknowledgments}

We want to thank Tepecik excavation team and especially Erhan Bıçakçı and Yasin Gökhan Çakan for their help. Thanks are due to Martin Godon for his constant support. 


\section{REFERENCES}

Bıçakçı, E., Godon, M., Büyükkarakaya, A.M., Erturaç, K., Kuzucuoğlu, C., Çakan, Y.G. and Vinet, A., 2017: "Les fouilles de Tepecik-Çiftlik et les activités du programme Melendiz préhistorique, campagne 2016", Anatolia Antiqua XXV: 71-94.

Bıçakçı, E., Godon, M. and Çakan, Y.G., 2012: "Tepecik-Çiftlik", in M. Özdoğan, N. Başgelen and P.I. Kuniholm (eds.), Central Turkey, Archaeology and Art Publications, Istanbul: 89-134.

Binder, D., 2007: "PPN Pressure Technology: views from Anatolia", in L. Astruc, D. Binder, and F. Briois (eds.), Systèmes techniques et communautés du Néolithique précéramique au Proche-Orient, Actes du $5^{e}$ colloque international, Fréjus, 2004, Antibes: 235-243.

Borrell, F., 2017: "La technologie de débitage laminaire bipolaire au Proche-Orient durant le Néolithique précéramique B (PPNB)", Journal of Lithic Studies 4: 1-33.

Borrell, F. and Khalaily, H., 2016: "Reconstructing the last stages of bidirectional blade technology in the Levant: North and South (Dis)connections", Paléorient 42-2: 73-95.

Godon, M., 2008: Les productions céramiques d'Anatolie centrale, développements culturels et phénomènes d'expansion du Néolithique céramique entre 7000 et 5500
$B C$ cal., Thèse de Doctorat, Université Paris X-Nanterre, Nanterre, 683 p.

Keeley, L.H., 1980: Experimental determination of stone tool uses: a microwear analysis, University of Chicago Press, (Prehistoric archeology and ecology), Chicago, 212 p.

Milić, M., Brown, K.E. and Carter, T., 2013: “Appendix 21.1: A Visual Characterisation of the Çatalhöyük Obsidian", in I. Hodder (dir.), Substantive Technologies at Çatalhöyük: Reports from the 2000-08 Seasons, British Institute at Ankara.

Özbaşaran, M. and Duru, G., 2014: "Istanbul (IST) Area of the East Mound", in I. Hodder (dir.), Catalhöyük Excavations: The 2000-2008 Seasons. Çatalhöyük Research Project Volume 7, The Cotsen Institute of Archaeology Press published in association with the British Institute of Archaeology at Ankara: 621-658.

Pelegrin, J., 2012: "New Experimental Observations for the Characterization of Pressure Blade Production Techniques", in P.M. Desrosiers (ed.), The Emergence of Pressure Blade Making from Origin to Modern Experimentation, Springer, Boston: 465-500.

Tringham, R. et al., 1974: "Experimentation in the Formation of Edge Damage: A New Approach to Lithic Analysis", Journal of Field Archaeology 1, 1/2: 171-196. 


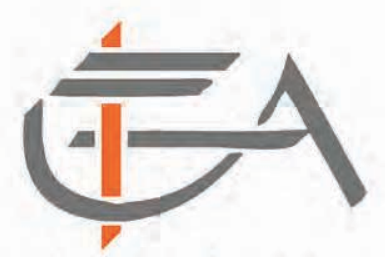

Institut Français d'Etudes Anatoliennes

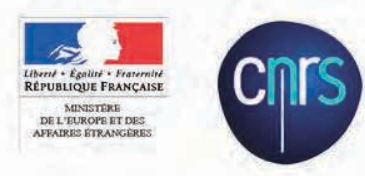

La citadelle de Tushpa (Van, Turquie).

ISBN: 978-2-36245-074-7

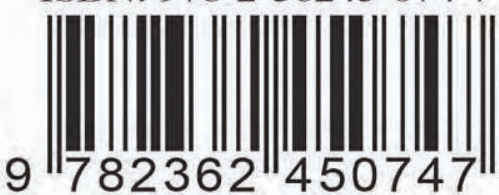

